\title{
PENGARUH PENGGANTIAN JAGUNG DENGAN MOLASES TERHADAP PERFORMA TERNAK KELINCI
}

\author{
Monica Sengkey, Y. L. R Tulung*, R. Tuturoong, Y. H. S Kowel \\ Fakultas Peternakan Universitas Sam Ratulangi Manado, 95115
}

\begin{abstract}
ABSTRAK
Penelitian ini bertujuan untuk mengetahui pengaruh penggunaan molases terhadap performa ternak kelinci. Penelitian menggunakan 25 ekor kelinci lepas sapih berumur 6 minggu dan menggunakan kandang individu. Setiap unit kandang ditempati 1 ekor kelinci. Rancangan yang digunakan adalah Rancangan Acak Lengkap (RAL) yang terdiri dari 5 perlakuan dan 5 ulangan dengan tingkat pemberian molases dalam pakan yaitu R0: 0\%, R1: 25\%, R2: 50\%, R3: $75 \%$ dan R4: $100 \%$. Variabel yang diukur yaitu, konsumsi pakan, pertambahan berat badan, konversi pakan dan konsumsi energi. Hasil penelitian menunjukkan rataan konsumsi pakan yaitu 78,07 - 95,20 g.ekor ${ }^{-1}$. ari $^{-1}$, pertambahan berat badan 9,7 - 12,02 g.ekor ${ }^{-1}$.hari ${ }^{-1}$, konversi pakan 7,90 - 8,71 g.ekor ${ }^{-1}$. hari $^{-1}$ dan konsumsi energi 2732,54 - 3076,10 Kkal/Kg. Berdasarkan hasil analisis keragaman, penggunaan molases sebagai pengganti jagung memberikan pengaruh yang berbeda sangat nyata $(\mathrm{P}<0,01)$ terhadap konsumsi pakan, pertambahan berat badan dan konsumsi energi. Berdasarkan penelitian ini dapat disimpulkan bahwa molases dapat menggantikan jagung sampai dengan level $75 \%$ atau $35.25 \%$ dalam bahan pakan ternak kelinci.
\end{abstract}

Kata kunci: Molases, jagung, kelinci, konsumsi pakan, pertambahan berat badan,

*Korepondensi(corresponding author)

Email: tulungyohannnis@gmail.com

\section{ABSTRACT}

\begin{tabular}{|c|c|}
\hline THE & EFFECT \\
\hline REPLACEMENT & CORN \\
\hline RATION WITH & MOLASSES \\
\hline
\end{tabular}
conducted to determine effect of molasses use replacing corn in ration on the performance of rabbits. The study used 25 weaned rabbits at age of 6 weeks old under individual cages. Each cage unit was occupied by 1 rabbit. The design used was a Completely Randomized Design (CRD) consisting of 5 treatments and 5 replications was applied in this study. Rates of giving molasses in feed were as follows: Ration containing corn without molasses (R0), Ration replacing corn of $25 \%$ with molasses (R1), Ration replacing corn of $50 \%$ with molasses (R2), Ration replacing corn of $75 \%$ with molasses (R3), and Ration replacing corn of $100 \%$ with molasses (R4). The measured variables were including feed consumption, weight gain, feed conversion and energy consumption. The results showed that the averages of feed consumption were 78.07 to $95.20 \mathrm{~g} / \mathrm{head} / \mathrm{day}$, weight gain were 9.7 to $12.02 \mathrm{~g} / \mathrm{head} /$ day, feed conversion were 7.90 to $8.71 \mathrm{~g} / \mathrm{head} /$ day and energy consumption were 2732.54 to 3076.10 $\mathrm{Kcal} / \mathrm{Kg}$. Based on the results analysis, the use of molasses substituting corn had a significantly different effect $(\mathrm{P}<0.01)$ on feed consumption, weight gain and energy consumption. Based on this research it can be concluded that molasses can replace corn up to the level of $75 \%$ or $35.25 \%$ in rabbit animal feed ingredients.

Keywords: Molasses, corn, rabbit, feed intake, weight gain. 


\section{PENDAHULUAN}

Kelinci adalah ternak yang memiliki prospek baik untuk dikembangkan. Kelinci memiliki kemampuan biologis yang tinggi, selang beranak yang pendek dan mampu beranak banyak (Moningkey et al., 2016). Kelinci memiliki kemampuan tumbuh dan berkembang biak dengan cepat serta dapat memanfaatkan pakan yang berasal dari limbah pertanian maupun hasil samping industri pangan.

Pakan merupakan salah satu faktor yang mempengaruhi pertumbuhan kelinci, karena pertumbuhan yang optimal dipengaruhi oleh kualitas dan kuantitas pakan yang dikonsumsi ternak. Kelinci dapat memanfaatkan hijauan dan limbah industri pertanian dengan efisien dan dapat mencerna hijauan dengan kandungan serat kasar yang tinggi. Konsentrat yang diberikan biasanya meliputi jagung, kacang hijau, padi, kacang tanah, sorgum, dedak dan beberapa jenis bungkil. Salah satu bahan penyusun ransum yang digunakan saat ini masih bersaing dengan kebutuhan manusia seperti jagung. Untuk itu perlu dicari bahan pakan alternatif sumber energi yang murah, tidak bersaing dengan kebutuhan manusia, mudah didapat, dan memiliki nilai nutrisi yang baik.

Molases merupakan hasil sampingan pada industri pengolahan gula berbentuk cair. Molases merupakan sumber energi dengan kandungan gula didalamnya, sehingga telah banyak dimanfaatkan sebagai bahan tambahan pakan ternak dengan kandungan nutrisi atau zat gizi yang cukup baik. Molasses dapat dijadikan salah satu bahan penyusun ransum ditinjau dari zat-zat makanan yang terkandung didalamnya.

Penelitian dilaksanakan untuk mengetahui pengaruh penggantian jagung dengan molasses terhadap konsumsi pakan, pertambahan berat badan, konversi pakan dan konsumsi energi ternak kelinci.

\section{MATERI DAN METODE PENELITIAN}

Penelitian ini menggunakan 25 ekor kelinci lokal lepas sapih umur 6 minggu dengan berat badan awal 500-600 gram/ekor yang diperoleh dari peternakan rakyat di desa Rurukan. Kandang yang digunakan selama penelitian yaitu kandang individu yang terbuat dari balok, bambu dan kawat dengan ukuran 40 x 40 x $40 \mathrm{~cm}$. Setiap unit kandang ditempati 1 ekor kelinci. Penempatan ternak dan perlakuan ke setiap unit kandang dilakukan secara acak. Setiap kandang dilengkapi dengan tempat pakan (feeder) dan tempat minum (thought) yang terbuat dari plastik. Pakan yang digunakan terdiri dari konsentrat yang tersusun dari jagung, dedak halus, bungkil 
kelapa, tepung kedele, tepung ikan, dan molases. Pakan yang diberikan berbentuk pelet. Proses pembuatan pelet diawali dengan mencampur semua bahan pakan perlakuan sesuai dengan komposisi yang sudah dihitung, kemudian tambahkan molases sesuai dengan komposisi ransum selama penelitian, dicampur sampai merata, selanjutnya masukkan ke dalam mesin pembuat pelet. Pelet yang keluar dianginanginkan terlebih dahulu sebelum disimpan di dalam karung. Komposisi kandungan zat makanan bahan pakan disajikan pada Tabel 1 dan susunan bahan pakan penyusun ransum dan komposisi nutrien disajikan pada Tabel 2. Susunan pakan sebagai berikut: $\mathrm{R}_{0}=$ Jagung $100 \%, \mathrm{R}_{1}=$ Jagung $75 \%+25 \%$ molases, $\mathrm{R}_{2}=$ Jagung $50 \%+$ $50 \%$ molases, $\mathrm{R}_{3}=$ Jagung $25 \%+75 \%$ molasses dan $\mathrm{R}_{4}=$ Molases $100 \%$.

$$
\text { Penelitian ini menggunakan }
$$
Rancangan Acak Lengkap menurut Steel and Torrie (1995), dengan model matematis sebagai berikut :

$$
\mathrm{Y}_{i j}=\mu+\tau_{i}+\Sigma_{i j}
$$

$\mathrm{Y}_{\mathrm{ij}} \quad$ : Variabel yang akan dianalisis pada ulangan ke-i ulangan ke-j

$\mu \quad$ : Nilai tengah (rata-rata)

$\tau_{\mathrm{i}} \quad$ : Pengaruh perlakuan ke-i

$\Sigma_{\mathrm{ij}} \quad$ : Galat percobaan pada perlakuan ke-i ulangan ke-j

\begin{tabular}{|c|c|c|c|c|c|c|c|}
\hline Bahan Pakan & $\begin{array}{c}\text { Protein } \\
(\%)\end{array}$ & $\begin{array}{l}\text { Lemak } \\
(\%)\end{array}$ & $\begin{array}{l}\text { SK } \\
(\%) \\
\end{array}$ & $\begin{array}{c}\text { Calsium } \\
(\%)\end{array}$ & $\begin{array}{c}\text { Fosfor } \\
(\%)\end{array}$ & $\begin{array}{l}\text { Abu } \\
(\%)\end{array}$ & $\begin{array}{c}\mathrm{EM} \\
(\mathrm{Kkal} / \mathrm{kg})\end{array}$ \\
\hline Jagung Kuning ${ }^{1)}$ & 5,37 & 3,31 & 2,39 & 0,01 & 0,33 & 15,13 & 3229 \\
\hline Dedak Halus $^{1)}$ & 7,91 & 5,94 & 17,98 & 0,02 & 0,72 & 10,33 & 3680 \\
\hline Bungkil Kelapa $^{1)}$ & 22,35 & 16,4 & 16,74 & 0,02 & 0,51 & 6,95 & 3922 \\
\hline Tepung Ikan ${ }^{1)}$ & 35,16 & 17,08 & 1,29 & 5,09 & 2,12 & 20,1 & 3847 \\
\hline Bungkil Kedele $^{1)}$ & 39,57 & 1,45 & 3,01 & 0,24 & 0,58 & & 3384 \\
\hline Daun Wortel $^{2)}$ & 3,61 & 2,23 & 1,38 & & & & 420 \\
\hline Molases $^{3)}$ & 4,2 & 0,2 & 0,4 & 0,74 & 0,08 & 9,9 & 2460 \\
\hline
\end{tabular}

Tabel 1. Komposisi Kandungan Zat Makanan Bahan Pakan

Keterangan: ${ }^{1)}$ Hasil analisis Lab. Pusat Penelitian Sumber Daya Hayati dan Bioteknologi IPB dan Lab. Ilmu dan Teknologi pakan IPB, 2016

${ }^{2)}$ Mas'ud et al. (2015) 
Tabel 2. Susunan Bahan Pakan Penyusun Ransum dan Komposisi Nutrien

\begin{tabular}{lccccc}
\hline Bahan pakan & $\mathrm{R} 0$ & $\mathrm{R} 1$ & $\mathrm{R} 2$ & $\mathrm{R} 3$ & $\mathrm{R} 4$ \\
& $(\%)$ & $(\%)$ & $(\%)$ & $(\%)$ & $(\%)$ \\
\hline Jagung Kuning & 47 & 3.25 & 23.5 & 11.75 & 0 \\
Dedak Halus & 7 & 7 & 7 & 7 & 7 \\
Bungkil Kelapa & 27 & 27 & 27 & 27 & 27 \\
Tepung Ikan & 5 & 5 & 5 & 5 & 5 \\
Tepung Kedele & 14 & 14 & 14 & 14 & 14 \\
Molases & 0 & 11.75 & 23.5 & 35.25 & 47 \\
\hline Total & 100 & 100 & 100 & 100 & 100 \\
\hline Komposisi Nutrien* & & & & & \\
\hline Protein (\%) & 16,56 & 16,12 & 16,2 & 16,02 & 15,9 \\
Serat Kasar (\%) & 7,38 & 7,15 & 6,9 & 6,69 & 6,45 \\
Lemak (\%) & 7,45 & 7,08 & 6,71 & 6,36 & 6 \\
Ca & 0,28 & 0,36 & 0,45 & 0,54 & 0,62 \\
P & 0,52 & 0,48 & 0,45 & 0,42 & 0,4 \\
Energi Metabolis (Kkal/kg) & 3500,28 & 3408,4 & 3291,12 & 3231,13 & 3138,85 \\
\hline
\end{tabular}

Keterangan: * Dihitung berdasarkan Tabel 1

\section{HASIL DAN PEMBAHASAN}

Hasil penelitian tentang pengaruh perlakuan terhadap performa ternak kelinci dapat dilihat pada Tabel 3.

\section{Pengaruh Perlakuan Terhadap Konsumsi Pakan}

Nilai rataan konsumsi pakan masing-masing perlakuan dalam penelitian ini berkisar antara 78,07 - 95,20 g.ekor ${ }^{1}$.hari ${ }^{-1}$. Hasil penelitian ini lebih tinggi dibandingkan dengan hasil penelitian dari Ensminger (1991) yang disitasi Dedi et al. (2016) yang menyatakan bahwa konsumsi pakan kelinci berkisar antara 75,70 - 88,90 g.ekor ${ }^{-1} \cdot$ hari $^{-1}$. Menurut Anggorodi (1979) konsumsi pakan dipengaruhi oleh umur, kesehatan ternak, palatabilitas, mutu pakan dan cara pemberian pakan itu sendiri. Pernyataan tersebut didukung Polii et al. (2015) dimana salah satu faktor yang mempengaruhi konsumsi pakan adalah palatabilitas.

Berdasarkan hasil analisis keragaman menunjukan bahwa penggunaan molases dalam ransum memberikan pengaruh yang berbeda sangat nyata $(\mathrm{P}<0,01)$ terhadap konsumsi kelinci. Uji lanjut BNJ menunjukkan terdapat perbedaan yang nyata $(\mathrm{P}<0,05)$ antara perlakuan $\mathrm{R} 0$ dengan R1, R2, R3, R4 dan perlakuan R1 dengan R2, R3, R4. Adapun perbedaan yang tidak nyata $(\mathrm{P}>0,05)$ antara perlakuan R2 dengan R3 dan R4, perlakuan R3 dengan R4. Data pada Tabel 3 menunjukkan bahwa konsumsi ransum meningkat seiring dengan bertambahnya 
level substitusi jagung dengan molases dalam pakan. Pakan yang diberikan dalam penelitian ini berbentuk pelet sehingga tingginya konsumsi pakan dalam penelitian ini juga diduga karena pemberian pakan dalam bentuk pelet yang memiliki tekstur, bau, rasa yang wangi dan bentuk pelet yang utuh dan kuat sehingga lebih banyak pakan yang dikonsumsi ternak kelinci. Nugroho et al. (2012) menyatakan bahwa pakan yang diberikan dalam bentuk pelet mempengaruhi konsumsi pakan, dimana pakan dalam bentuk pelet lebih disukai dibanding dengan pakan dalam bentuk mash. Namun ternyata peningkatan konsumsi hanya sampai pada perlakuan R3 (konsentrat $25 \%+$ molasses $75 \%$ ). Perlakuan R3 nyata lebih tinggi dibanding perlakuan R0, R1, R2 dan R4. Konsumsi pakan pada perlakuan R4 (konsentrat 0\%+ molasses 100\%) menunjukkan konsumsi pakan yang menurun secara nyata. Menurunnya konsumsi pakan pada perlakuan R4 dalam penelitian ini diduga karena kandungan energi sudah tercukupi sehingga ternak kelinci merasa lebih cepat kenyang dibanding dengan pakan perlakuan lainnya. Qisthon (2012) menambahkan bahwa kelinci akan berhenti makan apabila energi yang dikonsumsi telah cukup untuk kebutuhan metabolisme. Suhu kandang dan suhu lingkungan juga diduga sebagai faktor lain yang menyebabkan konsumsi pakan dalam dikonsumsi telah cukup untuk kebutuhan metabolisme. Suhu kandang dan suhu lingkungan juga diduga sebagai faktor lain yang menyebabkan konsumsi pakan dalam lingkungan juga diduga sebagai faktor lain yang menyebabkan konsumsi pakan dalam penelitian ini lebih tinggi. Rataan suhu kandang yang ideal bagi ternak kelinci yaitu berkisar antara pagi $23^{\circ} \mathrm{C}$, siang $28^{\circ} \mathrm{C}$ dan malam $26^{\circ} \mathrm{C}$. Selama penelitian ini dilaksanakan tercatat bahwa suhu kandang berkisar antara $21^{\circ} \mathrm{C}$ pagi, $33^{\circ} \mathrm{C}$ siang dan $25^{\circ} \mathrm{C}$ pada malam hari. Muhidin (2015) menjelaskan bahwa tinggi rendahnya konsumsi pakan disebakan oleh suhu kendang dan suhu lingkungan

Tabel 3. Rataan Konsumsi Pakan, PBB, Konversi Pakan dan Konsumsi Energi

\begin{tabular}{lccccc}
\hline Variabel & $\mathrm{R} 0$ & $\mathrm{R} 1$ & $\mathrm{R} 2$ & $\mathrm{R} 3$ & $\mathrm{R} 4$ \\
\hline Konsumsi & $78,07^{\mathrm{a}}$ & $88,51^{\mathrm{b}}$ & $93,25^{\mathrm{c}}$ & $95,20^{\mathrm{c}}$ & $94,94^{\mathrm{c}}$ \\
PBB & $9,7^{\mathrm{a}}$ & $10,22^{\mathrm{a}}$ & $11,9^{\mathrm{b}}$ & $12,02^{\mathrm{c}}$ & $11,56^{\mathrm{c}}$ \\
Konversi & 8,07 & 8,71 & 7,93 & 7,90 & 8,23 \\
Konsumsi energi & $2732,54^{\mathrm{a}}$ & $3016,77^{\mathrm{b}}$ & $3069,03^{\mathrm{b}}$ & $3076,10^{\mathrm{b}}$ & $2980,08^{\mathrm{b}}$ \\
\hline
\end{tabular}

Keterangan : Huruf yang berbeda pada baris yang sama menunjukkan perbedaan yang nyata $(\mathrm{P}<0.01)$ 
sekitar. Pernyataan tersebut didukung oleh Sampul (2018) dimana salah satu faktor yang mempengaruhi konsumsi pakan adalah suhu kandang. Suhu kandang yang tidak ideal akan mempengaruhi tingkat konsumsi pakan.

\section{Pengaruh Perlakuan Terhadap Pertambahan Berat Badan}

Rataan pertambahan berat badan dari masing-masing perlakuan dapat dilihat pada Tabel 3 yaitu antara 9,7 - 12,02 g.ekor ${ }^{-1} \cdot$ hari $^{-1}$. Menurut Cheeke (1982) dalam Polii et al. (2015) bahwa pertumbuhan kelinci pada daerah tropis berkisar antara $10-20$ g.ekor ${ }^{-1}$.hari ${ }^{-1}$.

Hasil analisis keragaman menunjukan pemberian molases memberikan pengaruh yang berbeda sangat nyata $(\mathrm{P}<0,01)$ terhadap pertambahan berat badan kelinci. Uji lanjut BNJ menunjukan terdapat perbedaan yang nyata $(\mathrm{P}<0,05)$ antara perlakuan R0 dengan $\mathrm{R} 2$, R3, R4 dan perlakuan R1 dengan R2, R3, R4. Adapun perbedaan yang tidak berbeda nyata $(\mathrm{P}>0,05)$ antara perlakuan $\mathrm{R} 0$ dengan R1, R2 dengan R3 dan R2 dengan R4. Pertambahan berat badan ternak kelinci paling tinggi terdapat pada perlakuan R3 yaitu 12,02 g.ekor ${ }^{-1}$.hari ${ }^{-1}$, sedangakan pertambahan berat badan ternak kelinci paling rendah yaitu pada perlakuan R0 yaitu 9,7 g.ekor $^{-1}$.hari ${ }^{-1}$.
Hasil analisis keragaman menunjukan bahwa pertambahan berat badan ternak kelinci dalam penelitian ini meningkat secara nyata $(\mathrm{P}<0.05)$ dengan semakin meningkatnya penggunaan molases dalam pakan sampai dengan R3 (konsentrat 25\% + molases $75 \%$ dalam pakan). Angka pertambahan berat badan ternak kelinci dalam penelitian ini mengikuti pola konsumsi pakan. Konsumsi pakan dan pertambahan berat badan terjadi sampai pada perlakuan R3. Kartadisastra (2001) menyatakan bahwa bobot badan berbanding lurus dengan tingkat konsumsi pakannya. Namun pada perlakuan R4 konsumsi pakan dan pertambahan berat badan ternak kelinci menurun secara nyata ( $\mathrm{P}<0,01)$. Hal ini diduga karena pakan yang diberikan sudah tidak saling melengkapi (complementary effect) dimana pada perlakuan R4 molases diberikan dalam jumlah 100\% sehingga zat gizi yang tersedia dalam jagung (terutama protein) tidak ada lagi dalam ransum R4. Menurut Hendayana dan Togatorp (2013), kebutuhan ransum kelinci dapat dipengaruhi oleh faktor genetik, status fisiologis, umur, lingkungan, jenis kelamin dan tingkat produksi masing-masing atau secara dikombinasi dapat mempengaruhi bentuk dan komposisi tubuh atau pertambahan berat badan. 


\section{Pengaruh Perlakuan Terhadap Konversi Pakan}

Nilai rataan konversi pakan dalam penelitian ini berkisar antara 7,90 - 8,71 $\left(\right.$ g.ekor $^{-1} \cdot$ hari $^{-1}$ ). Wuysang et al. (2015) melaporkan hasil penelitiannya yang menyatakan bahwa rataan konversi pakan ternak kelinci umur $2-3$ bulan berkisar 4,93-6,60 (g.ekor ${ }^{-1} \cdot$ hari $\left.^{-1}\right)$.

Hasil analisis menunjukkan bahwa perlakuan memberikan pengaruh yang tidak berbeda nyata $(\mathrm{P}>0.05)$. Hasil konversi pakan ini diduga karena pakan yang diberikan sudah sesuai untuk kebutuhan produksi ternak. Cheeke (1999) menyatakan bahwa konversi pakan dipengaruhi oleh kemampuan ternak dalam mencerna bahan pakan, kecukupan zat pakan untuk kebutuhan hidup pokok, pertumbuhan dan fungsi tubuh lain serta jenis pakan yang dikonsumsi. Menurut Anggorodi (1979) faktor lain yang mempengaruhi tinggi rendahnya konversi pakan yaitu kualitas pakan, galur atau keturunan dan manajemen pemberian pakan.

\section{Pengaruh Perlakuan Terhadap Konsumsi Energi}

Nilai rataan konsumsi energi masing-masing perlakuan dalam penelitian ini berkisar antara 2732,54 - 3976,10 Kkal/Kg. Menurut NRC (1977) kebutuhan energi pada kelinci untuk pertumbuhan dan hidup pokok adalah $2500-2900 \mathrm{Kkal} / \mathrm{Kg}$.

Hasil analisis keragaman menunjukkan konsumsi energi memberikan pengaruh yang berbeda sangat nyata $(\mathrm{P}<0.01)$. Uji lanjut $\mathrm{BNJ}$ menunjukkan terdapat perbedaan yang nyata $(\mathrm{P}<0.05)$ antara perlakuan $\mathrm{R} 0$ dengan R1, R2, R3 dan R4. Adapun perbedaan yang tidak berbeda nyata $(\mathrm{P}>0.05)$ antara perlakuan R1 dengan R2 dan R3, perlakuan $\mathrm{R} 2$ dengan $\mathrm{R} 3$ dan perlakuan $\mathrm{R} 4$ dengan R1, R2 dan R3.

Nilai konsumsi energi dalam penelitian ini sejalan dengan nilai konsumsi pakan. Menurut Aritonang et al. (2017) dalam Agustin et al. (2017) bahwa konsumsi energi meningkat seiring bertambahnya konsumsi pakan. Tingkat energy dalam pakan merupakan faktor yang menentukan banyaknya pakan yang dikonsumsi oleh ternak, karena kelinci mengkonsumsi makanan untuk memenuhi kebutuhan energinya. Nuriyasa et al. (2013) menambahkan bahwa ternak kelinci mengkonsumsi energi untuk pertumbuhan jaringan tubuh, kebutuhan hidup pokok dan produksi. Kebutuhan energi sangat bervariasi tergantung dari beberapa faktor seperti umur, ukuran tubuh, status fisiologis, temperatur lingkungan dan kandungan serat dalam pakan (NRC, 1977). Mas'ud et al. (2015) menyatakan, tidak semua energi yang terkandung dalam pakan 
dapat dipergunakan oleh ternak, sebagian akan terbuang melalui feses dan urin.

\section{KESIMPULAN}

Molases dapat menggantikan jagung sampai dengan level $75 \%$ atau 35,25\% dalam bahan pakan kelinci karena memberikan pengaruh yang baik terhadap konsumsi pakan, pertambahan berat badan, konversi pakan dan konsumsi energi.

\section{DAFTAR PUSTAKA}

Anggorodi. 1979. Ilmu Makanan Ternak Umum. PT Gramedia. Jakarta

Cheeke, P. R. 1999. Applied Animal Nutrition. Feeds and Feeding. Mac Millan Publ. Co. New York. Collier Mac Millan Canada. Toronto. Feeding dan Nutrition of rabbit. Pp4425-430.

Dedi, M., I Wayan Pasek., Rossuartini., dan B, Brahmantiyo. 2016. Tatalaksana Pemberian Pakan Untuk Menunjang Agribisnis Ternak Kelinci. Lokakarya Nasional Potensi dan Peluang Pengembangan Usaha Kelinci. Balai Penelitian Ternak Bogor.

Hendayana, R dan M. H. Togatorp. 2003. Struktur waktu kerja dan pendapatan peternak. JITV Volume III: 318-323.

Kartadisastra, H. R. 2001. Beternak Kelinci Unggul. Kanisius. Yogyakarta.

Mas'ud, C. S., Y. R. L. Tulung, J. Umboh, C. A. Rahasia. 2015. Pengaruh pemberian beberapa jenis hijauan terhadap perfomans ternak kelinci. Jurnal Zootek 35(2): 289-294.

Moningkey, S., M. Junus, O. Sjofjan, E. Widodo. 2016. Nutritive value evaluation on rumen content angsludge fermented with Cellulomonas Sp. as rabbit feed. International Journal of Cemtech Research 09(4): 650-656.

Muhidin, A. 2015. Perfoma kelinci local yang diberi air minum rebusan daun sirih (Pipper Betle Linn). Jurnal Peternakan Nusantara 1(2):105113.

NRC. 1977. Nutrient Requirement Of Rabbit. 2nd revised edition. National Academy Of Sciences. Washington DC. P 10.

Nugroho, S. S., P.S.B. Subur dan Panjono. 2012. pengaruh penggunaan konsentrat dalam bentuk pelet dan mash pada pakan dasar rumput lapangan terhadap palatabilitas dan kinerja produksi kelinci jantan. Buletin Peternakan 36(3): 169-173.

Nuriyasa, I. M., I. M. Mastika, A.W. Puger, E. Puspani dan I.W. Wirawan. Performans kelinci lokal (Lepus Migricolis) yang diberi ransum dengan kandungan energi berbeda. Majalah Ilmiah Peternakan 16(1):

Polii, P., K. Maaruf, Y. Kowel, H. Liwe, Y. C. Raharjo. 2015. Pengaruh penambahan zat aditif (enzim dan asam organic) dengan protein tinggi dan rendah pada pakan bebasis dedak terhadap performa kelinci. Jurnal Zootek 35(2): 280-288.

Pratiwi, A., Supadmo, A. Astuti dan Panjono. 2017. Kinerja pertumbuhan dan produks karkas kelinci rex yang diberi pakan dengan suplemenasi 
minyak jagung. Buletin

Peternakan Vol. 41(2):119-125

Qishton, A. 2012. Pengaruh imbangan hijauan-konsentrat dan waktu pemberian ransum terhadap produktivitas kelinci lokal jantan. Jurnal Penelitian Pertanian Tarapan 12(2):69-74.

Sampul, M. B. 2018. Pengaruh pemanfaatan daun ubi jalar (Ipome Batatas L) terhadap performans Ternak kelinci. Jurnal Zootek 37(1): 314-319.

Steel, R. C., dan Torrie J. H. 1995. Prinsip dan Prosedur Statistika. Gramedia Pustaka Utama. Jakarta.

Wuysang, S., C. A. Rahasia, J. F. Umboh, Y. L. R. Tulung. Pengaruh penggunaan molases sebagai sumber energi pakan penguat dalam ransum terhadap pertumbuhan ternak kelinci. Jurnal Zootek 37(1): 149-155. 